\title{
Overexpression of ER $\alpha$ inhibits proliferation and invasion of MKN28 gastric cancer cells by suppressing $\beta$-catenin
}

\author{
JICHUN ZHOU $^{1 *}$, RONGYUE TENG $^{1 *}$, CHAOYANG XU $^{3}$, QINCHUAN WANG $^{1}$, JUFENG GUO ${ }^{1}$, \\ CHENPU XU ${ }^{1}$, ZIDUO LI ${ }^{1}$, SHUDUO XIE ${ }^{1}$, JIANGUO SHEN ${ }^{1}$ and LINBO WANG ${ }^{1,2}$ \\ ${ }^{1}$ Department of Surgical Oncology, Sir Run Run Shaw Hospital, Zhejiang University School of Medicine, Hangzhou, \\ Zhejiang 310016; ${ }^{2}$ Biomedical Research Center and Key Laboratory of Biotherapy of Zhejiang Province, \\ Hangzhou, Zhejiang 310016; ${ }^{3}$ Department of Breast and Thyroid Surgery, Shaoxing People's Hospital, \\ The First Affiliated Hospital of Shaoxing Liberal Art College, Shaoxing, Zhejiang 312000, P.R. China
}

Received April 5, 2013; Accepted June 3, 2013

DOI: 10.3892/or.2013.2610

\begin{abstract}
The relationship between estrogen receptor (ER) $\alpha$ and patient prognosis has been identified in gastric cancer; however, the definite role of ER $\alpha$ in gastric cancer remains to be fully elucidated. The aim of the present in vitro study was to investigate the impact of $\mathrm{ER} \alpha$ on cell proliferation, migration and invasion in gastric cancer cell lines. We investigated the biological effect of ER $\alpha$ overexpression on gastric carcinoma cells. An MKN28 gastric cancer cell line stably overexpressing $\mathrm{ER} \alpha$ was established. The effect of ER $\alpha$ overexpression on cell growth was assessed by evaluating cell survival, colony formation, cell cycle progression and apoptosis. Cell migration and invasion were detected by Transwell migration/invasion assays. The protein levels of several potentially involved genes were determined by western blotting to elucidate the underlying molecular mechanisms. The Student's t-test was used to determine the statistical differences between various experimental and control groups, and one-way ANOVA test was used to determine the difference between three or more groups. The results showed that ER $\alpha$ overexpression significantly inhibited cell growth and proliferation, blocked cell entry into the G1/G0 phase and promoted cell apoptosis. In addition, ER $\alpha$ reduced the motility and invasion of gastric cancer cells. These phenotypes may partly be explained by a decrease in $\beta$-catenin expression caused by ER $\alpha$ overexpression. ER $\alpha$ overexpression effectively inhibited cell growth and cancer progression by suppressing $\beta$-catenin in gastric cancer,
\end{abstract}

Correspondence to: Dr Jianguo Shen or Professor Linbo Wang, Department of Surgical Oncology, Sir Run Run Shaw Hospital, Zhejiang University School of Medicine, Eastern Qingchun Road, Hangzhou, Zhejiang 310016, P.R. China

E-mail: drshenjianguo@yahoo.com.cn

E-mail:wanglinbo@medmail.com.cn

*Contributed equally

Key words: ER $\alpha$, gastric cancer, MKN28, proliferation, metastasis identifying ER $\alpha$ as a promising target with therapeutic potential for development of new approaches to treat gastric cancer.

\section{Introduction}

Although the incidence of gastric cancer has been declining globally since World War II, and it is one of the least common cancers in North America, the incidence of gastric cancer is still high in many countries around the world. In 2012, an estimated 21,320 new cases were diagnosed, and 10,540 cases will eventually die of the disease in the United States (1). Gastric cancer is estimated to be the fourth most common cancer worldwide (2)

Despite a major decline in the incidence of gastric cancer and substantial breakthroughs in our understanding of gastric cancer both from a clinical as well as a preclinical perspective over the past decades, gastric cancer remains a significant public health burden worldwide, particularly in developing countries. Hence, it is urgent to develop novel therapeutics for gastric cancer. The pathogenesis of gastric carcinoma is still unclear, and increasing evidence shows that many factors contribute to this process.

In the past three decades, utilization of the estrogen receptor (ER) in breast carcinoma is well established. Women with ER-positive breast cancer benefit by substantial improvements in outcomes due to current endocrine therapies $(3,4)$. Unfortunately, the role of the ER in other types of cancers is largely unknown. Estrogen receptor (ER) $\alpha$ expression in human gastric cancer was first reported by Tokunaga et al (5). Since that time, the relationship between ER $\alpha$ status and tumor progression was reported in a series of studies. Our previous study demonstrated that ER $\alpha$ status strongly influences patient survival in gastric cancer (37). It is tempting to postulate that ER $\alpha$ may play an essential role in the carcinogenesis of gastric cancer; however, its definitive role in the cell biological characteristics and related involved mechanisms have not yet been fully elucidated. Better understanding of the role of ER $\alpha$ as well as the related pathway will lead to more effective targeting of this pathway for cancer prevention and therapy. 
The present study aimed to investigate the involvement of ER $\alpha$ in cell growth and progression in gastric cancer. To accomplish this, we constructed an eukaryotic expression vector with the ER $\alpha$ gene to determine the effects of ER $\alpha$ overexpression on the cell biological characteristics of the gastric cancer cell line MKN28. The long-term goals of our research are to ascertain whether ER $\alpha$ may serve as a potential diagnostic and prognostic marker of gastric cancer and as a target for the development of therapeutic approaches to treat this disease.

\section{Materials and methods}

Cell culture. Human gastric adenocarcinoma cell lines, BGC823, KATOIII, MKN45, MKN28, AGS, N87 and SGC7901, were purchased from the Cell Bank, Chinese Academy of Science, Shanghai, China. They were cultured in an incubator at $37^{\circ} \mathrm{C}$ under a humidified atmosphere of $5 \%$ $\mathrm{CO}_{2}$ and $95 \%$ air in Dulbecco's modified Eagle's medium (DMEM) (Invitrogen, Life Technologies, Gaithersburg, MD, USA). All media were supplemented with $10 \%$ heat-inactivated fetal bovine serum (FBS) (Invitrogen Life Technologies), penicillin $(100 \mathrm{U} / \mathrm{ml})$ and streptomycin $(100 \mu \mathrm{g} / \mathrm{ml})$. Cells were incubated for $24 \mathrm{~h}$ in Phenol red-free minimum essential medium (MEM; Invitrogen Life Technologies, Carlsbad, CA, USA) without FBS prior to all experiments (termed cell cycle synchronization).

Construction and transfection of the ER $\alpha$ plasmid expression vector. We used plasmid pcDNA3.1+ (Shanghai Cancer Institute, China) to construct the ER $\alpha$ expression vector. The methods of pcDNA3.1+ER $\alpha$ and transfection of MKN28 gastric cancer cells with pcDNA3.1+ (vector) or pcDNA3.1+ER $\alpha$ were conducted as follows. Briefly, an ER $\alpha$ cDNA PCR product and pcDNA3.1+ (vector) were digested with EcoRI. The digested PCR product was electrophoresed through and isolated from an agarose gel. After purification, it was ligated into the cut vector to form pcDNA3.1+ER $\alpha$. After the ligation, the plasmid was transformed into Escherichia coli TOP10 cells, and then planted on solid LB medium. Ampicillin-resistant colonies were cultured at $37^{\circ} \mathrm{C}$ overnight in a rocking bed. The recombinant plasmid was prepared, and the sequences were verified by electrophoresis of the digested product. MKN28 cells $\left(1 \times 10^{5}\right)$ were inoculated into a 6 -well plate and transfected with pcDNA3.1+ or pcDNA3.1+ER $\alpha$ recombination plasmids when the confluency achieved $90 \%$. Forty-eight hours after transfection, cells were diluted to 1:10 for passage, and cultured for at least 2 weeks in medium containing G418 (Geneticin ${ }^{\circledR}$ selection agent; Invitrogen Life Technologies, Carlsbad, CA, USA).

MTT assay. MKN28 cells with or without ER $\alpha$ overexpression (1x10 $3 /$ well) were seeded into a 96 -well plate and incubated in an incubator at $37^{\circ} \mathrm{C}$ under a humidified atmosphere of $5 \%$ $\mathrm{CO}_{2}$ and $95 \%$ air. Growth was measured by adding $20 \mu \mathrm{l}$ of $5 \mathrm{mg} / \mathrm{ml}$ methyl-thiazolyl-tetrazolium (MTT) to each well, and the plates were incubated at $37^{\circ} \mathrm{C}$ for $4 \mathrm{~h}$. Then, $200 \mu \mathrm{l}$ dimethyl sulfoxide was added to each well after removal of the old medium, and absorbance was measured at $570 \mathrm{~nm}$ using a multi-well spectrophotometer (Bio-Rad, Hercules, CA, USA).
Colony formation assay. Cell suspensions from each group were diluted in DMEM supplemented with 10\% FBS, and immediately re-plated (1,000 cells/well) in 6-well plates. The plates were incubated until the cells had formed sufficiently large colonies. The colonies were fixed with dehydrated ethanol and stained with $0.5 \%$ crystal violet. The plates were photographed and their digital images were manually analyzed to determine the colony number.

Flow cytometric analysis. For cell cycle analysis, cells $\left(1 \times 10^{6}\right)$ were washed twice with ice-cold PBS, treated with trypsin, and fixed in cold $70 \%$ ethanol at $4^{\circ} \mathrm{C}$ for at least $24 \mathrm{~h}$, washed twice in PBS, and incubated in $25 \mu \mathrm{g} / \mathrm{ml}$ of RNase for $30 \mathrm{~min}$ at $37^{\circ} \mathrm{C}$. Before analysis, cells were stained with $50 \mu \mathrm{g} / \mathrm{ml}$ of propidium iodide (PI) (Cell Apoptosis PI Detection kit; Keygentec, China) at room temperature for $30 \mathrm{~min}$. Analyses were performed using a FACScan flow cytometer (BectonDickinson, Sunnyvale, CA, USA). Data obtained from the cell cycle distributions were analyzed using FlowJo v7.6 (Tree Star, Inc., Ashland, OR, USA).

Analysis of apoptosis. Enumeration of apoptotic cells was carried out using the Cell Apoptosis PI Detection kit (Keygentec). Cells were washed twice in cold PBS and re-suspended in $1 \mathrm{X}$ buffer $\mathrm{A}$ at a concentration of $100 \times 10^{6}$ cells $/ \mathrm{ml}$. This suspension $(95 \mu \mathrm{l})$ was stained with $5 \mu \mathrm{l}$ of PI. The cells were gently vortexed and incubated for $5 \mathrm{~min}$ at room temperature in the dark. Cells were observed under a fluorescence microscope according to the protocol. The number of cells undergoing apoptotic cell death was analyzed by an inverted fluorescence microscope. Images were captured randomly from 5 fields of vision with x 200 magnification. Independent experiments were performed in triplicate.

Transwell migration and invasion assays. For the migration studies, cells with or without ER $\alpha$ overexpression were dispersed using trypsin and adjusted to a density of $1 \times 10^{6}$ cells $/ \mathrm{ml}$ with serum-free DMEM. Then, $100 \mu \mathrm{l}$ of the solution $\left(1 \times 10^{5}\right.$ cells $\left./ \mathrm{ml}\right)$ was placed in the upper chambers of Transwell plates (Millipore, Billerica, MA, USA), and $500 \mu \mathrm{l}$ of DMEM with $10 \%$ FBS was added to the lower chambers. The plates were then placed in an incubator at $37^{\circ} \mathrm{C}$ with $5 \%$ $\mathrm{CO}_{2}$ for $24 \mathrm{~h}$. After incubation, the cells remaining in the upper chamber were carefully removed, and the Transwell membrane was fixed with dehydrated ethanol and stained with $0.5 \%$ crystal violet. To count the fixed cells, images were captured randomly from 5 fields of vision with x 200 magnification. Independent experiments were performed in triplicate.

For the cell invasion assay, Matrigel (BD Biosciences, Franklin Lakes, NJ, USA) was thawed on ice at $4^{\circ} \mathrm{C}$ overnight and diluted with serum-free medium at a ratio of 1:3. Then, the Transwell chambers were coated with $30 \mu 1$ of diluted Matrigel in a 24-well plate and incubated at $37^{\circ} \mathrm{C}$ for $2 \mathrm{~h}$. Afterward, $1 \times 10^{5}$ cells in serum-free DMEM were seeded into the prepared Transwell chambers. Then, $500 \mu 1$ of DMEM with $10 \%$ FBS was added to the basal chamber. The 24-well plate was then incubated at $37^{\circ} \mathrm{C}$ with $5 \% \mathrm{CO}_{2}$ for $24 \mathrm{~h}$. Cells were stained and counted as in the migration assay. 


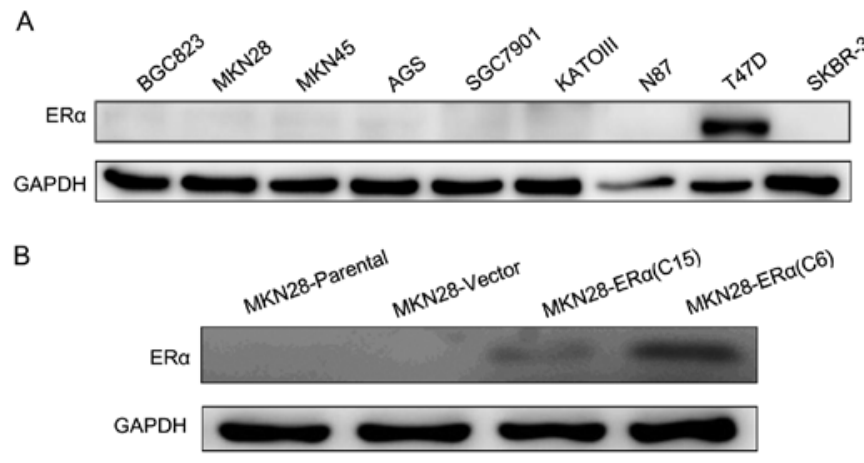

Figure 1. Expression of ER $\alpha$ in gastric cancer cell lines. (A) Western blot analysis of ER $\alpha$ expression in the indicated cancer cells. Breast cancer line T47D and SKBR-3 were used as positive and negative control, respectively. GAPDH was used as a loading control. (B) ER $\alpha$ expression in the transfected cell lines.

A

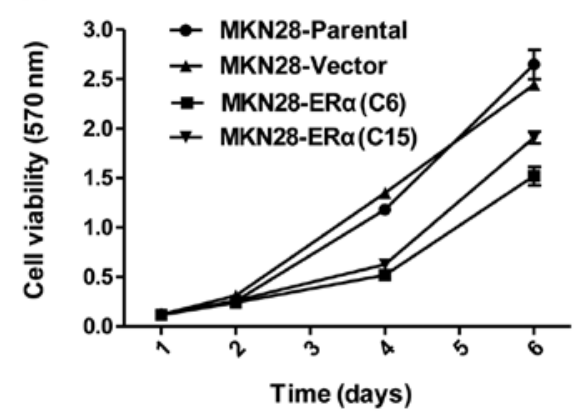

B

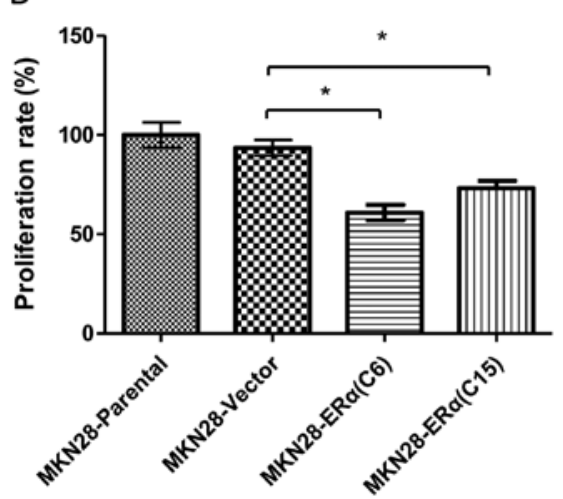

Figure 2. Cell survival was assessed by MTT assay. The results represent the means of at least 3 independent experiments. (A) The cell viability was observed after MTT treatment in the indicated cell lines on day 1,2,4 and 6. (B) The mean cell proliferation rate of MKN28-ER $\alpha(\mathrm{C} 6)$ and MKN28-ER $\alpha(\mathrm{C} 15)$ cells during a 5 day period following MTT treatment was significantly lower when compared with that of the MKN28-Vector or MKN28-Parental cells. " $\mathrm{P}<0.05$.

Western blot analysis. Whole-cell proteins were isolated using a protein extraction buffer containing $150 \mathrm{mmol} / \mathrm{l} \mathrm{NaCl}$, $10 \mathrm{mmol} / \mathrm{ml}$ Tris $(\mathrm{pH} 7.2), 5 \mathrm{mmol} / 1$ ethylenediaminetetraacetic acid, $0.1 \%$ Triton $\mathrm{X}-100,5 \%$ glycerol and $1 \%$ sodium dodecyl sulfate. Equal amounts (40 $\mu \mathrm{g} / \mathrm{lane})$ of proteins were fractionated on $10 \%$ sodium dodecyl sulfate polyacrylamide gels and transferred to polyvinylidene difluoride membranes. The membranes were probed with anti-ER $\alpha$ (Epitomics, Inc., Burlingame, CA, USA), -GAPDH (Santa Cruz Biotechnology Inc., Santa Cruz, CA, USA) and - $\beta$-catenin (Epitomics, Inc.) primary antibodies. After being washed with TBS Tween-20 $(0.1 \%)$, the membranes were incubated with peroxidase-conjugated rabbit anti-mouse or goat anti-rabbit secondary antibody (Santa Cruz Biotechnology, Inc.) for $2 \mathrm{~h}$ at room temperature and subjected to enhanced chemiluminescent staining using an ECL detection system (Bio-Rad). All experiments were conducted in triplicate.

Statistical analysis. Data are presented as means \pm standard error of the mean (SEM) of 3 independent experiments. The Student's t-test was used to determine the statistical differences between various experimental and control groups, and one-way ANOVA test was used to determine the difference between three or more groups. P-values $<0.05$ were considered to indicate statistically significant differences.

\section{Results}

ER expression in gastric cancer cell lines. Western blotting was performed using 7 gastric cancer cell lines. The protein level of ER $\alpha$ was not detectable in all 7 gastric cancer cell lines based on western blot analysis (Fig. 1A).

Construction and transfection with the pcDNA3.1+ER $\alpha$ recombinant vector. To examine the effect of ER $\alpha$ on gastric tumor cell progression in vitro, the plasmid pcDNA3.1 was used to construct the ER $\alpha$ expression vector, pcDNA3.1+ER $\alpha$. The MKN28 cell line was engineered to stably express increased levels of ER $\alpha$ protein, and the engineered cell lines are referred to as MKN28-ER $\alpha(\mathrm{C} 6)$ and MKN28$\mathrm{ER} \alpha(\mathrm{C} 15)$, respectively. A control cell line was transfected with the empty vector and is referred to as MKN28-Vector. $\mathrm{ER} \alpha$ protein was detectable in the MKN28-ER $\alpha(\mathrm{C} 6)$ and MKN28-ER $\alpha(\mathrm{C} 15)$ cells. In contrast, no ER $\alpha$ expression was observed in the MKN28-Vector cells (Fig. 1B). The data suggest that the pcDNA3.1+ER $\alpha$ recombinant vector was successfully constructed, and ER $\alpha$ was stably overexpressed in the MKN28-ER $\alpha(\mathrm{C} 6)$ and MKN28-ER $\alpha(\mathrm{C} 15)$ cells. Furthermore among the two cell lines expressing ER $\alpha$, MKN28-ER $\alpha(C 6)$ cells exhibited much higher expression than the other, which enabled us to examine how different 
A
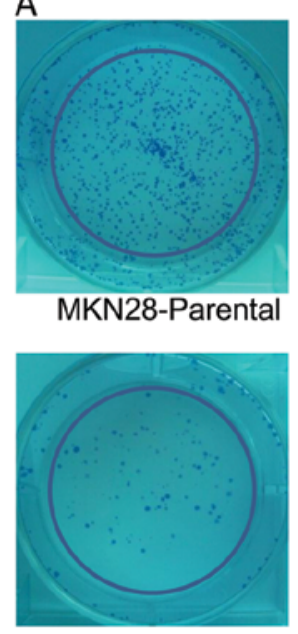

MKN28-ERa(C6)
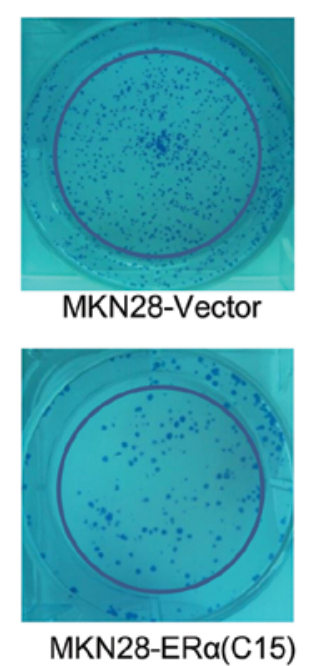

B

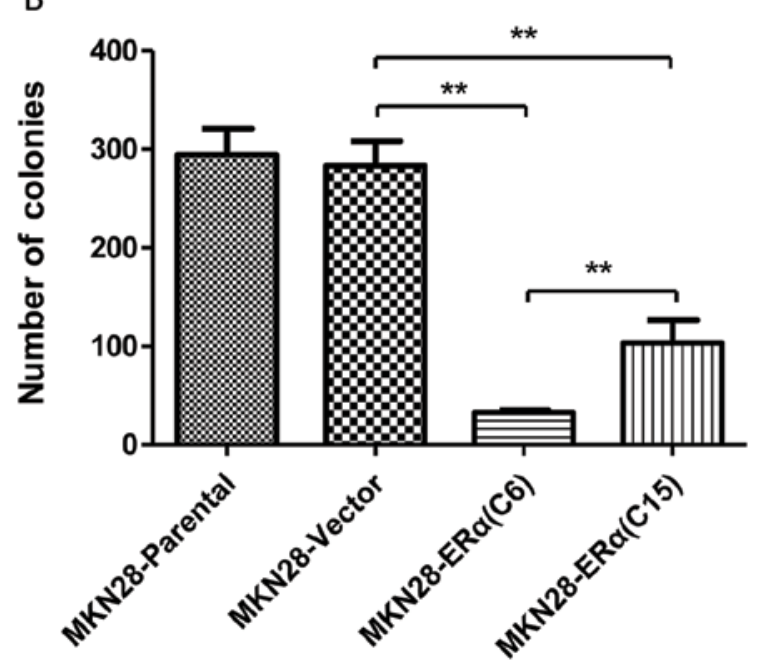

Figure 3. Results of the colony formation assay. (A) MKN28-Parental, MKN28-Vector, MKN28-ER $\alpha(\mathrm{C} 6)$ and MKN28-ER $\alpha(\mathrm{C} 15)$ cells were plated in 6-well plates. The surviving fraction of cells (visible colonies) was stained with Gentian violet, photographed and counted manually. (B) MKN28-ER $\alpha(\mathrm{C} 6)$ cells exhibited fewer colonies than the MKN28-ER $\alpha(\mathrm{C} 15)$, MKN28-Parental and MKN28-Vector cells. ${ }^{* *} \mathrm{P}<0.001$

A
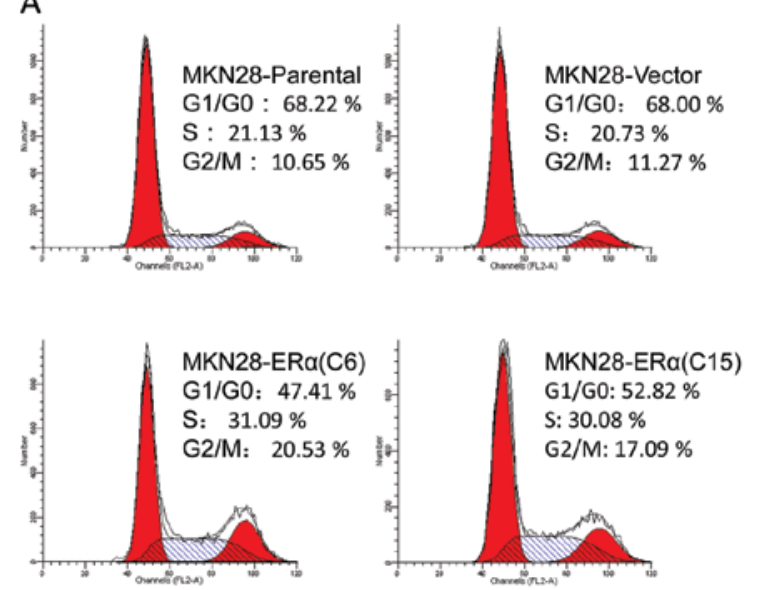

B

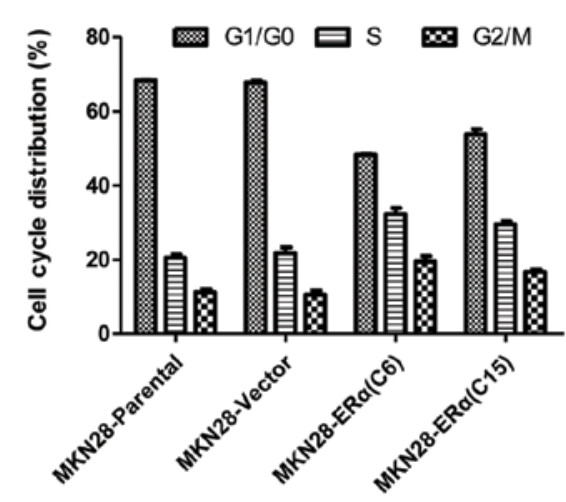

Figure 4. Cell growth inhibition by ER $\alpha$ is associated with cell cycle arrest at the G2/M phase. (A) Cell cycle analysis by flow cytometry in MKN28, MKN28-Vector and MKN28-ER $\alpha$ cells. Cell cycle distribution of propidium iodide (PI)-labeled cells was analyzed by flow cytometric analyses. The peaks in the illustration correspond to the G1/G0, S and G2/M phases of the cell cycle. (B) Histogram showing the percentages of cells in each phase of the cell cycle.

degrees of ER $\alpha$ expression influence the progression of MKN28 cell.

ER $\alpha$ overexpression inhibits cell growth and proliferation in gastric cancer MKN28 cells. To determine the effect of ER $\alpha$ expression on the growth and proliferation of MKN28, we determined the in vitro survival rates of the MKN28-ER $\alpha(\mathrm{C} 6)$ and MKN28-ER $\alpha(\mathrm{C} 15)$ cells. MKN28-ER $\alpha(\mathrm{C} 6)$ and MKN28-ER $\alpha(\mathrm{C} 15)$ cells exhibited significantly reduced cell survival, as assessed by the MTT assay (Fig. 2A). The mean proliferation rate was 1.2- to 1.5-fold higher in the MKN28Parental and MKN28-Vector cells when compared to the rate in the MKN28-ER $\alpha(\mathrm{C} 6)$ and $\mathrm{MKN} 28-\mathrm{ER} \alpha(\mathrm{C} 15)$ cells $(\mathrm{P}<0.05)$ (Fig. 2B). In addition, MKN28-ER $\alpha(\mathrm{C} 6)$ cells had a slower rate of growth than the MKN28-ER $\alpha(\mathrm{C} 15)$ cells, which was consistent with the elevated levels of ER $\alpha$ in MKN28$\mathrm{ER} \alpha(\mathrm{C} 6)$ cells.
We utilized a colony formation assay to further confirm the suppressive effect of ER $\alpha$ on the growth of MKN28 cells. The mean number of colonies formed by MKN28-ER $\alpha(\mathrm{C} 6)$ cells after 10 days of culture was $32.67 \pm 4.16$, and it was 59.7 and $62.1 \%$ decreased, respectively, when compared with that of the MKN28-Vector and MKN28 cells $(\mathrm{P}<0.001)$ (Fig. 3). Furthermore, more colonies were observed in the MKN28-ER $\alpha(\mathrm{C} 15)$ cells when compared to the number of colonies in the MKN28-ER $\alpha(\mathrm{C} 6)$ cells. Taken together, these data suggest that ER $\alpha$ inhibits cell growth and proliferation in gastric cancer MKN28 cells.

Effect of ER $\alpha$ overexpression on cell cycle control in gastric cancer MKN28 cells. Flow cytometry was used to determine whether the inhibitory effect of ER $\alpha$ on MKN28 cell proliferation was mediated, at least partly, by the cell cycle. Both MKN28-ER $\alpha(C 6)$ and MKN28-ER $\alpha(\mathrm{C} 15)$ cells showed an 


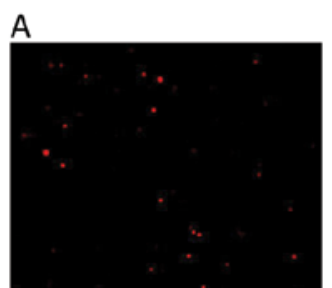

MKN28-Parental

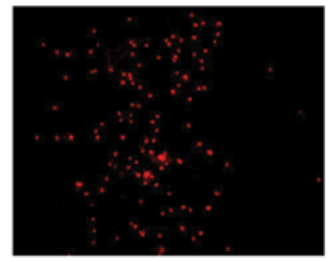

MKN28-ERa(C6)

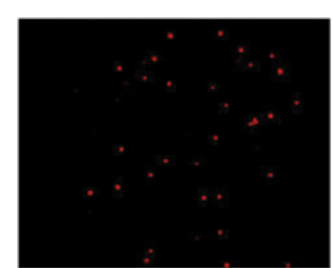

MKN28-Vector

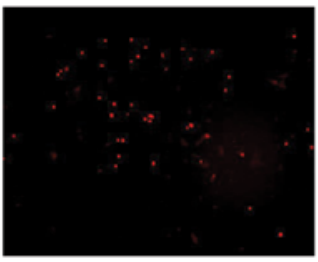

MKN28-ERa(C15)
B

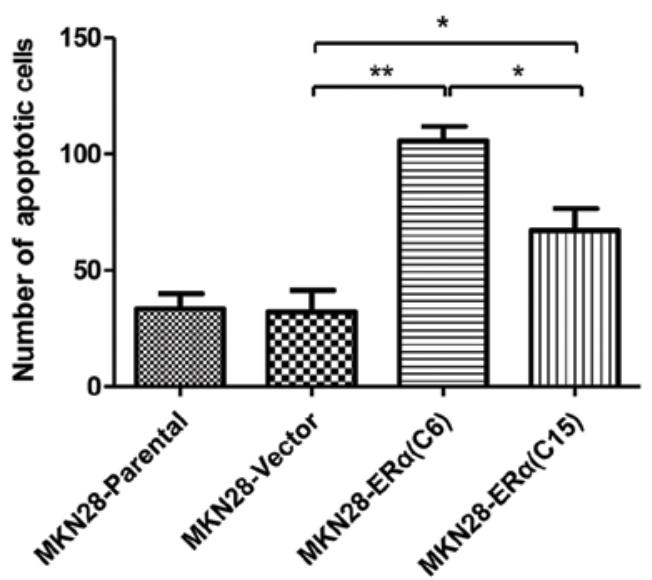

Figure 5. Cell apoptosis as detected by PI staining. (A) MKN28 cells were stained with propidium iodide (PI), and images were captured under a fluorescence microscope; magnification $x 200$. Representative results are shown for the indicated cell lines. (B) The results presented are an average of 5 random microscopic fields from 3 independent experiments. Bars indicate standard error, ${ }^{*} \mathrm{P}<0.05,{ }^{* *} \mathrm{P}<0.001$.
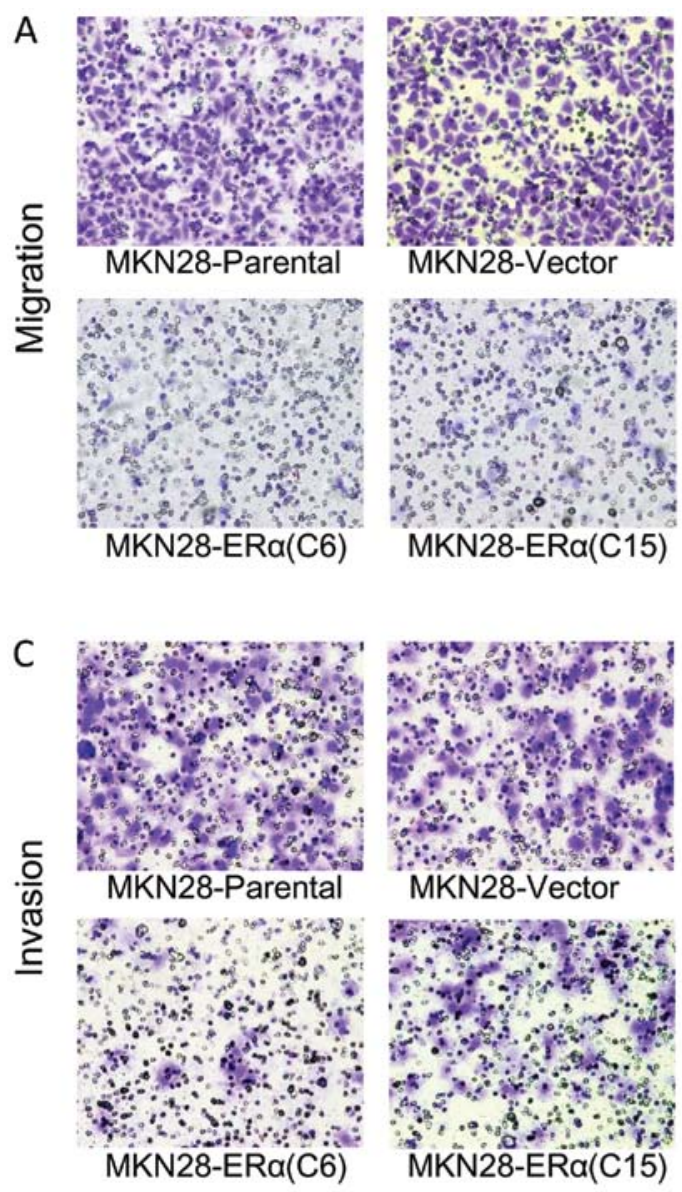

B

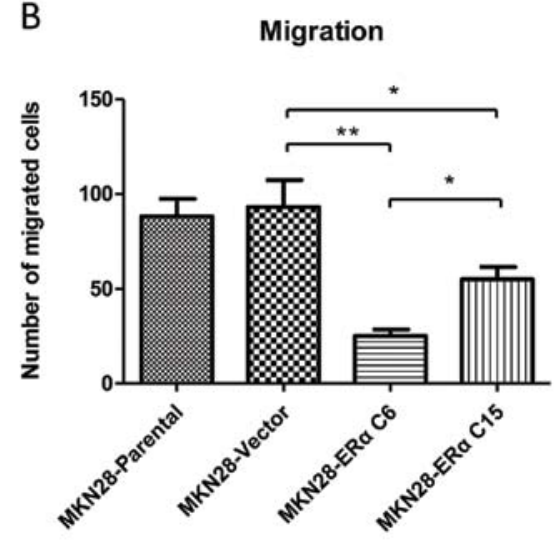

D

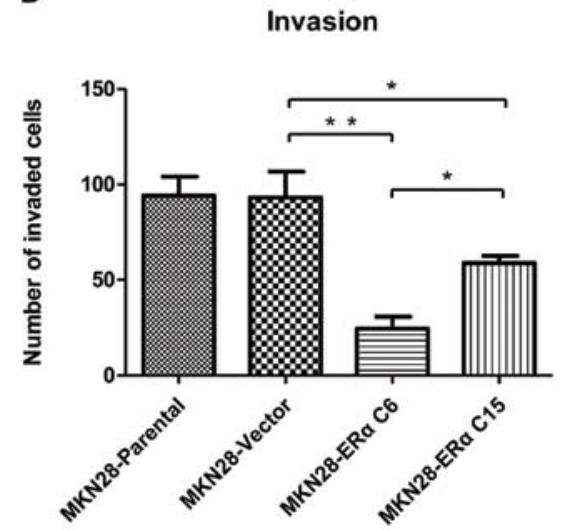

Figure 6. ER $\alpha$ overexpression inhibits migration and invasion abilities of MKN28 cells. (A and B) Cell migration was determined using Millipore Transwell chambers. (C and D) Cell invasion was assayed in Transwells coated with Matrigel. (A) and (C) Representative images of the bottom surface are shown. (B) and (D) The number of cells in five random microscopic fields (x200) were counted for each group. The results presented are an average of 5 random microscopic fields from 3 independent experiments. Date shown represent the means \pm standard errors of the means (SEM) of data from at least 3 independent experiments. ${ }^{*} \mathrm{P}<0.05 ;{ }^{* *} \mathrm{P}<0.001$.

increase in the number of G2-M-arrested cells, when compared to this number in the parental cells (Fig. 4). Cell growth inhibition by ER $\alpha$ was associated with significant cell cycle arrest at the $\mathrm{G} 2 / \mathrm{M}$ phase, implicating that ER $\alpha$ suppresses cell proliferation by controlling the $\mathrm{G} 2$ and $\mathrm{M}$ checkpoints and induces specific blockage of cell cycle progression. 


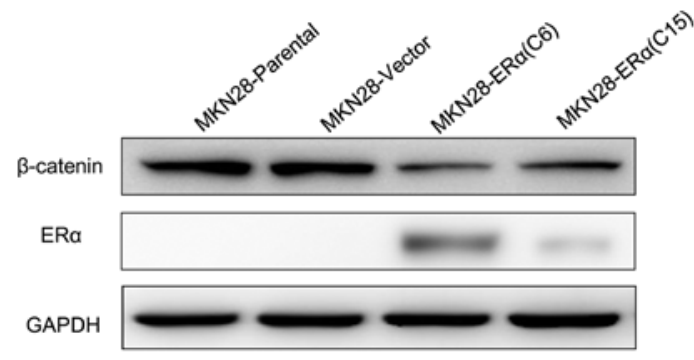

Figure 7. $\beta$-catenin protein level is reduced in the ER $\alpha$-overexpressing MKN28 cells. Total proteins were extracted from MKN28-Parental (lane 1), MKN28-Vector (lane 2), MKN28-ER $\alpha(\mathrm{C} 6)$ (lane 3) and MKN28-ER $\alpha(\mathrm{C} 15)$ (lane 4) cells, respectively. Proteins were resolved by SDS-polyacrylamide gel electrophoresis and analyzed by western blotting. The antibodies used in the western blot analysis are indicated on the left. GAPDH was used as a loading control.

ERa overexpression induces apoptosis of gastric cancer cells. PI staining was used to evaluate the degree of apoptosis in the different cell lines. There was a significantly increased number of apoptotic cells noted in the MKN28-ER $\alpha(\mathrm{C} 6)$ and MKN28$\mathrm{ER} \alpha(\mathrm{C} 15)$ cells, as compared with the MKN28-Parental and MKN28-Vector cells. Notably, the proportion of apoptotic cells in the MKN28-ER $\alpha$ cells was in line with the level of ER $\alpha$ expression (Fig. 5).

ER $\alpha$ overexpression inhibits the migration and invasion of gastric cancer cells. To determine whether ER $\alpha$ is involved in mediating the migration and invasion of gastric cancer cells, we performed in vitro migration and invasion assays using Transwell chambers. After the cells were incubated for $24 \mathrm{~h}$ in the Transwell assay system, the number of MKN28Vector cells that had moved through the membrane of the chamber was $\sim 3.7$ and 1.7-fold higher than the number of the MKN28-ER $\alpha(\mathrm{C} 6) \quad(\mathrm{P}<0.001)$ and MKN28-ER $\alpha(\mathrm{C} 15)$ cells $(\mathrm{P}<0.05)$ (Fig. 6A and B), respectively. MKN28-ER $\alpha$ cells migrated at a significantly lower rate than the control cells after $24 \mathrm{~h}$. The results indicate that ER $\alpha$ reduces the migratory ability of MKN28 cells.

Similarly, MKN28-ER $\alpha$ cells were observed to be less invasive. After the cells were incubated for $24 \mathrm{~h}$ in the Transwell assay system, the number of MKN28-Vector cells that had invaded through the membrane of the Matrigel chamber was $\sim 3.8$-fold higher than that of the MKN28$\mathrm{ER} \alpha(\mathrm{C} 6)$ cells $(\mathrm{P}<0.001)$ and 1.6-fold higher than that of the MKN28-ER $\alpha(C 15)$ cells $(\mathrm{P}<0.05)($ Fig. $6 \mathrm{C}$ and $\mathrm{D})$.

The migration and invasion ability was 2.2-fold reduced in the MKN28-ER $\alpha(\mathrm{C} 6)$ cells when compared to the MKN28-ER $\alpha(\mathrm{C} 15)$ cells (Fig. 6B and D). Taken together, these results showed that overexpression of ER $\alpha$ may suppress the migration and invasion of MKN28 cells.

Overexpression of ER $\alpha$ inhibits progression by suppressing $\beta$-catenin in MKN28 cells. Next, to determine the potential molecular mechanism of the phenotypes gained by ER $\alpha$ overexpression in MKN28 cells, we examined the protein level of $\beta$-catenin, as $\beta$-catenin has been implicated in the initiation and progression of gastric cancer $(6,7)$; interaction between $\mathrm{ER} \alpha$ and $\beta$-catenin has been delineated (8). Our results showed that $\beta$-catenin was significantly reduced in MKN28-ER $\alpha(\mathrm{C} 6)$ and MKN28-ER $\alpha(\mathrm{C} 15)$ cells, compared with the control cells (Fig. 7).

\section{Discussion}

In the present study, we investigated the role of ER $\alpha$ expression on the cell growth and metastasis of gastric cancer cell line MKN28. We observed that ER $\alpha$ protein was not expressed in the 7 gastric cell lines studied. ER $\alpha$ transfection inhibited cell growth by G2/M arrest, induced apoptosis, and suppressed cell migration and invasion in gastric cancer cell line MKN28. In addition, these inhibitory effects by ER $\alpha$ were in line with the level of ER $\alpha$ expression in gastric cancer. Our study also observed that the biological changes induced by ER $\alpha$ may possibly be through the suppression of $\beta$-catenin expression.

Estrogen protects against gastric cancer through ERs. Gastric cancer has an unexplained strong and enigmatic male predominance $(2: 1)(9,10)$, which cannot entirely be explained on the basis of gender differences in the prevalence of known risk factors (11). Accumulative evidence suggests that the differences are rooted in basic biological differences between men and women, and this phenomenon would be explained by the hypothesis that estrogens are protective in this respect (reviewed in ref. 12).

This hypothesis has gained support from a number of studies based on different aspects. Epidemiological studies have confirmed that estrogen exposure is associated with a decreased risk of developing gastric cancer (13-16). Women with a longer fertility life and those on hormone replacement therapy appear to have a decreased risk of gastric cancer. Furthermore, men who have been treated with estrogen for prostate cancer also have a decreased risk. In a meta-analyses, risks for ever vs. never use of hormone treatment (HT) were significantly reduced for gastric cancer (RR 0.78 , confidence interval (CI) 0.65-0.94; $\mathrm{P}=0.008$ ) (17). A nested case-control study of hormone replacement therapy (HRT) demonstrated that a greater than $50 \%$ reduced risk of gastric adenocarcinoma was found among users of HRT compared to nonusers [odds ratio (OR), 0.48, 95\% CI 0.29-0.79] (18). Furthermore, tamoxifen (TAM) an anti-estrogen, may increase the risk of gastric cancer and accelerate tumor progression $(19,20)$.

On the contrary, Harrison et al (21) demonstrated that estradiol caused significant stimulation of gastric cell lines at physiologic concentrations, meanwhile, addition of the active metabolite of the estrogen-receptor blocker/partial-agonist 4-hydroxytamoxifen had a stimulating effect on the growth rate of the gastric cell lines. On the other hand, another study reported that estrogen did not affect the proliferation of gastric cancer cell lines (22). Despite these contradictory results, in animal studies, female and castrated rats have a lower incidence of chemically induced gastric cancer (23). This hypothesis was further validated by animal studies (23-26). These preclinical studies indicate that estrogen may offer protection against the development of gastric cancer, as for example, ovariectomized mice are at an increased risk, while administration of female sex hormones decreases the incidence of gastric cancer.

The biological means behind this hypothesis is still inconclusive but various mechanisms have been suggested. 
Estrogen exerts its biological actions through the activation of two nuclear receptors, $\mathrm{ER} \alpha$ and $\mathrm{ER} \beta$, with distinctive tissue distribution and a counteracting function (27-29). In addition, $\mathrm{ER} \alpha$ has been proven to have a critical role in gastric cancer, which will be subsequently discussed. It is therefore reasonable to hypothesize that estrogen may protect women against gastric cancer through the ER $\alpha$ pathway.

ER $\alpha$ is involved in the development and progression of gastric cancer. The discovery of the ER $\alpha$ provided us not only with a powerful predictive and prognostic marker, but also an efficient target for the treatment of hormone-dependent breast cancer with anti-estrogens. The important role of ER $\alpha$ in the development, progression and treatment of breast cancer are well established, but the role of such an evaluation in other types of cancers is largely unknown.

$\mathrm{ER} \alpha$ expression in human gastric cancer was first reported by Tokunaga et al (5) as far back as in 1986. Nonetheless, the role of ER $\alpha$ in human gastric cancer is not yet fully elucidated. It has been suggested that the ER $\alpha$ pathway may have a role in the progression of gastric cancer $(5,22,30-32)$. Contradictory findings have emerged on the basis of publicly accessible in vivo and in vitro studies. We found that numerous investigators have reported the relationship of $\mathrm{ER} \alpha$ status to carcinogenesis and tumor progression; even though, their findings are still controversial (33-36), including our previous study (37). Most recently, another study indicated that sex hormone receptors (including $\mathrm{ER} \alpha$ ) may be partly involved in gastric carcinogenesis yet their clinicopathological and prognostic significance in gastric cancer appears to be limited (38). The possibility exists that these discrepancies result from small numbers and inconsistencies in methodologies.

Based on the evidence that $\mathrm{ER} \alpha$ is expressed in poorly differentiated adenocarcinomas more frequently than in well differentiated gastric cancer (39-43), several clinical trials using a partial estrogen antagonist, tamoxifen, have been conducted for the management of ER $\alpha$-positive gastric cancer patients. However, the results have not been consistent, and the utility of ER $\alpha$ for the treatment of gastric cancer is still inconclusive $(21,39,44,45)$.

Even more, the expression of ER $\alpha$ in gastric cancer has shown marked variability $(0-62.5 \%)(12,46)$. Consistent with our result, several studies also found that $\mathrm{ER} \alpha$ cannot be detected in gastric cancer cell lines $(46,47)$.

Based on the currently available evidence, the clinical significance and implication of $\mathrm{ER} \alpha$ expression in human gastric carcinoma are still not fully elucidated. Elucidation of the precise roles of estrogen and/or its receptors in gastric cancer will provide new insights that will contribute to diagnosis and treatment.

Role of $\beta$-catenin in gastric cancer. Wnt and estrogen signaling represent important regulatory pathways, each controlling a wide range of biological processes. Crosstalk between Wnt and estrogen signaling pathways via functional interaction between $\beta$-catenin and ER $\alpha$ (8), can provide fine-tuned regulation of many cellular processes. In the present study, we aimed to ascertain whether ER $\alpha$ plays a suppressive role in the proliferation and metastasis of MKN28 cells through altering $\beta$-catenin expression.
The roles of $\beta$-catenin in mediating intercellular adhesion and regulation of cell growth, differentiation, invasion and metastasis have been well characterized $(48,49)$. The $\beta$-catenin-TCF/LEF complex regulates and activates its downstream target transcription genes which are involved in the development and progression of cancer (50-52). The abnormal activation of $\beta$-catenin frequently occurs in gastric cancer and has been proven to promote tumor growth, invasion and metastasis $(6,7)$. Furthermore, previous studies have confirmed that high $\beta$-catenin expression is an independent indicator of poor prognosis for these carcinomas and is closely correlated with enhanced tumor progression $(53,54)$.

In the present study, expression of $\beta$-catenin was found to be notably decreased in ER $\alpha$-overexpressing MKN28 cells (Fig. 7). Importantly, the degree of decrease was in line with the level of ER $\alpha$ expression in the two different MKN28-ER $\alpha$ cells.

Limitation of this present study and future perspectives. These preliminary findings will require further replication and in-depth investigation. In our present study, only one gastric cancer cell line MKN28 was studied. Thus, it would be sensible to reanalyze our findings using another gastric cancer cell line to reconfirm our results and to exclude a cell-specific phenomenon.

In addition, cell lines do not always accurately represent the phenotype of the tumors from which they were derived. Therefore, in vivo studies using xenografts should be embarked on in the near future.

It should also be noted that this study was primarily concerned with gain-of-function analysis of the biological effect of overexpression of ER $\alpha$ in MKN28 cells. Unfortunately as mentioned above, none of the 7 gastric cancer cell lines in our study had an inherent ER $\alpha$ protein level expression. Because of this reason, we could not provide evidence whether inhibition of ER $\alpha$ promotes the aggressive phenotype of gastric cancer cells.

Additionally, based on the present study, whether or not the effect of ER $\alpha$ is estrogen mediated was not directly determined. Nonetheless, estrogen-free Dulbecco's modified Eagle's medium (DMEM) was used in this study, which can exclude the influence of estrogen. An estrogen-containing condition should be further investigated, to delineate whether $\mathrm{ER} \alpha$ can exhibit a further suppressive effect on the malignant phenotype of MKN28 cells in the context of the presence of estrogen.

Finally, the specific mechanism between ER $\alpha$ and $\beta$-catenin interaction needs to be further clarified.

In conclusion, despite its preliminary character, the research reported here indicates that overexpression of ER $\alpha$ inhibits tumor cell proliferation, migration and invasion. To the best of our knowledge, this is the first finding that demonstrates that $\mathrm{ER} \alpha$ expression is a possible protective mechanism against the progression of gastric cancer and suggests that $\mathrm{ER} \alpha$ may be a potential target for utilization in gastric cancer treatment.

\section{Acknowledgements}

This study was supported by grants from the National Natural Science Foundation of China (grant no. 81101659/H1609, 
81101659), the Natural Science Foundation of Zhejiang Province (grant no. Y2110073), the Science and Health Care Foundation of Zhejiang Province (grant no. 2011KYA086), and the Program for Innovative Research Team in Zhejiang Province (grant no. 2010R50046).

\section{References}

1. Siegel R, Naishadham D and Jemal A: Cancer statistics, 2012. CA Cancer J Clin 62: 10-29, 2012.

2. Kamangar F, Dores GM and Anderson WF: Patterns of cancer incidence, mortality, and prevalence across five continents: defining priorities to reduce cancer disparities in different geographic regions of the world. J Clin Oncol 24: 2137-2150, 2006.

3. Clarke M, Collins R, Davies C, et al: Tamoxifen for early breast cancer: an overview of the randomised trials. Early Breast Cancer Trialists' Collaborative Group (EBCTCG). Lancet 351: 1451-1467, 1998.

4. Abe O, Abe R, Enomoto K, et al: Effects of chemotherapy and hormonal therapy for early breast cancer on recurrence and 15-year survival: an overview of the randomised trials. Early Breast Cancer Trialists' Collaborative Group (EBCTCG). Lancet 365: 1687-1717, 2005

5. Tokunaga A, Nishi K, Matsukura N, et al: Estrogen and progesterone receptors in gastric cancer. Cancer 57: 1376-1379, 1986.

6. Bianchi F, Hu J, Pelosi G, et al: Lung cancers detected by screening with spiral computed tomography have a malignant phenotype when analyzed by cDNA microarray. Clin Cancer Res 10: 6023-6028, 2004.

7. Zhang N, Zhang J, Shuai L, et al: Krüppel-like factor 4 negatively regulates $\beta$-catenin expression and inhibits the proliferation, invasion and metastasis of gastric cancer. Int J Oncol 40 2038-2048, 2012.

8. Kouzmenko AP, Takeyama K, Ito $\mathrm{S}$, et al: Wnt/ $\beta$-catenin and estrogen signaling converge in vivo. J Biol Chem 279 40255-40258, 2004

9. Crew KD and Neugut AI: Epidemiology of gastric cancer. World J Gastroenterol 12: 354-362, 2006.

10. Brenner H, Rothenbacher D and Arndt V: Epidemiology of stomach cancer. Methods Mol Biol 472: 467-477, 2009.

11. Parkin D, Whelan S, Ferlay J, Teppo L and Thomas D: Cancer incidence in five continents. Volume VIII. IARC Sci Publ 155 $1-781,2002$.

12. Chandanos E and Lagergren J: Oestrogen and the enigmatic male predominance of gastric cancer. Eur J Cancer 44: 2397-2403, 2008.

13. La Vecchia C, D'Avanzo B, Franceschi S, Negri E, Parazzini F and Decarli A: Menstrual and reproductive factors and gastric-cancer risk in women. Int J Cancer 59: 761-764, 1994.

14. Frise S, Kreiger N, Gallinger S, Tomlinson G and Cotterchio M Menstrual and reproductive risk factors and risk for gastric adenocarcinoma in women: findings from the Canadian National Enhanced Cancer Surveillance system. Ann Epidemiol 16: 908-916, 2006

15. Lindblad M, Ye W, Rubio C and Lagergren J: Estrogen and risk of gastric cancer: a protective effect in a nationwide cohort study of patients with prostate cancer in Sweden. Cancer Epidemiol Biomarkers Prev 13: 2203-2207, 2004.

16. Freedman ND, Chow WH, Gao YT, et al: Menstrual and reproductive factors and gastric cancer risk in a large prospective study of women. Gut 56: 1671-1677, 2007.

17. Green J, Czanner G, Reeves G, et al: Menopausal hormone therapy and risk of gastrointestinal cancer: nested case-control study within a prospective cohort, and meta-analysis. Int J Cancer 130: 2387-2396, 2012.

18. Lindblad M, García Rodríguez LA, Chandanos E and Lagergren J: Hormone replacement therapy and risks of oesophageal and gastric adenocarcinomas. Br J Cancer 94: 136-141, 2006.

19. Chandanos E, Lindblad M, Jia C, Rubio CA, Ye W and Lagergren J: Tamoxifen exposure and risk of oesophageal and gastric adenocarcinoma: a population-based cohort study of breast cancer patients in Sweden. Br J Cancer 95: 118-122, 2006.

20. Chandanos E, Lindblad M, Rubio CA, et al: Tamoxifen exposure in relation to gastric adenocarcinoma development. Eur J Cancer 44: 1007-1014, 2008.
21. Harrison JD, Watson S and Morris DL: The effect of sex hormones and tamoxifen on the growth of human gastric and colorectal cancer cell lines. Cancer 63: 2148-2151, 1989.

22. Takano N, Iizuka N, Hazama S, Yoshino S, Tangoku A and Oka M: Expression of estrogen receptor- $\alpha$ and $-\beta$ mRNAs in human gastric cancer. Cancer Lett 176: 129-135, 2002.

23. Furukawa $\mathrm{H}$, Iwanaga $\mathrm{T}$, Koyama $\mathrm{H}$ and Taniguchi $\mathrm{H}$ : Effect of sex hormones on carcinogenesis in the stomachs of rats. Cancer Res 42: 5181-5182, 1982.

24. Campbell-Thompson M, Lauwers GY, Reyher KK, Cromwell $\mathrm{J}$ and Shiverick KT: $17 \beta$-estradiol modulates gastroduodenal preneoplastic alterations in rats exposed to the carcinogen $N$-methyl- $N$ '-nitro-nitrosoguanidine. Endocrinology 140: 4886-4894, 1999.

25. Furukawa H, Iwanaga T, Hiratsuka M, et al: Suppressive effect of sex hormones on spreading of stomach cancer. Gan To Kagaku Ryoho 16: 3691-3695, 1989 (In Japanese).

26. Furukawa H, Iwanaga T, Koyama $\mathrm{H}$ and Taniguchi $\mathrm{H}$ : Effect of sex hormones on the experimental induction of cancer in rat stomach - a preliminary study. Digestion 23: 151-155, 1982.

27. Greene GL, Gilna P, Waterfield M, Baker A, Hort Y and Shine J: Sequence and expression of human estrogen receptor complementary DNA. Science 231: 1150-1154, 1986.

28. Kuiper GG, Enmark E, Pelto-Huikko M, Nilsson S and Gustafsson JA: Cloning of a novel estrogen receptor expressed in rat prostate and ovary. Proc Natl Acad Sci USA 93: 5925-5930, 1996.

29. Green S, Walter P, Kumar V, et al: Human oestrogen receptor cDNA: sequence, expression and homology to v-erb-A. Nature 320: 134-139, 1986.

30. Wu CW, Chang YF, Yeh TH, et al: Steroid hormone receptors in three human gastric cancer cell lines. Dig Dis Sci 39: 2689-2694, 1994.

31. Karat D, Brotherick I, Shenton BK, Scott D, Raimes SA and Griffin SM: Expression of oestrogen and progesterone receptors in gastric cancer: a flow cytometric study. Br J Cancer 80 : 1271-1274, 1999

32. Chandanos E, Rubio CA, Lindblad M, et al: Endogenous estrogen exposure in relation to distribution of histological type and estrogen receptors in gastric adenocarcinoma. Gastric Cancer 11: $168-174,2008$.

33. Matsui M, Kojima O,Uehara Y and Takahashi T: Characterization of estrogen receptor in human gastric cancer. Cancer 68: 305-308, 1991.

34. Wu CW, Lui WY, P'eng FK and Chi CW: Hormonal therapy for stomach cancer. Med Hypotheses 39: 137-139, 1992.

35. Machado JC, Carneiro F, Gärtner F, Ribeiro P and SobrinhoSimões M: Female sex hormone receptors are not involved in gastric carcinogenesis. A biochemical and immunohistochemical study. Eur J Cancer Prev 3: 31-37, 1994.

36. Singh S, Poulsom R, Wright NA, Sheppard MC and Langman MJ: Differential expression of oestrogen receptor and oestrogen inducible genes in gastric mucosa and cancer. Gut 40: 516-520, 1997.

37. Xu CY, Guo JL, Jiang ZN, et al: Prognostic role of estrogen receptor $\alpha$ and estrogen receptor $\beta$ in gastric cancer. Ann Surg Oncol 17: 2503-2509, 2010.

38. Gan L, He J, Zhang X, et al: Expression profile and prognostic role of sex hormone receptors in gastric cancer. BMC Cancer 12: 566,2012

39. Kitaoka H: Sex hormone dependency and endocrine therapy in diffuse carcinoma of the stomach]. Gan To Kagaku Ryoho 10: 2453-2460, 1983 (In Japanese).

40. Matsui M, Kojima O, Kawakami S, Uehara Y and Takahashi T: The prognosis of patients with gastric cancer possessing sex hormone receptors. Surg Today 22: 421-425, 1992.

41. Zhao XH, Gu SZ, Liu SX and Pan BR: Expression of estrogen receptor and estrogen receptor messenger RNA in gastric carcinoma tissues. World J Gastroenterol 9: 665-669, 2003.

42. Yokozaki H, Takekura N, Takanashi A, Tabuchi J, Haruta R and Tahara E: Estrogen receptors in gastric adenocarcinoma: a retrospective immunohistochemical analysis. Virchows Arch A Pathol Anat Histopathol 413: 297-302, 1988.

43. Wang M, Pan JY, Song GR, Chen HB, An LJ and Qu SX: Altered expression of estrogen receptor $\alpha$ and $\beta$ in advanced gastric adenocarcinoma: correlation with prothymosin $\alpha$ and clinicopathological parameters. Eur J Surg Oncol 33: 195-201, 2007. 
44. Kitaoka H: Chemo-endocrine therapy of diffuse carcinoma of the stomach and its clinical evaluation. Gan No Rinsho 31: 1189-1194, 1985 (In Japanese).

45. Koullias GJ, Pratsinis CI, Korkolis DP, et al: Brief tamoxifen pretreatment enhances the chemosensitivity of gastric carcinoma cells to 5-fluorouracil in vitro. Anticancer Res 23: 1575-1580, 2003.

46. Matsuyama S, Ohkura Y, Eguchi H, et al: Estrogen receptor $\beta$ is expressed in human stomach adenocarcinoma. J Cancer Res Clin Oncol 128: 319-324, 2002.

47. Ryu WS, Kim JH, Jang YJ, et al: Expression of estrogen receptors in gastric cancer and their clinical significance. J Surg Oncol 106: 456-461, 2012

48. Ozawa M, Ringwald M and Kemler R: Uvomorulin-catenin complex formation is regulated by a specific domain in the cytoplasmic region of the cell adhesion molecule. Proc Nat Acad Sci USA 87: 4246-4250, 1990.

49. Conacci-Sorrell M, Simcha I, Ben-Yedidia T, Blechman J, Savagner P and Ben-Ze'ev A: Autoregulation of E-cadherin expression by cadherin-cadherin interactions: the roles of $\beta$-catenin signaling, Slug, and MAPK. J Cell Biol 163: 847-857, 2003.
50. Logan CY and Nusse R: The Wnt signaling pathway in development and disease. Annu Rev Cell Dev Biol 20: 781-810, 2004.

51. Kanwar SS, Yu Y, Nautiyal J, Patel BB and Majumdar AP: The Wnt/ $\beta$-catenin pathway regulates growth and maintenance of colonospheres. Mol Cancer 9: 212, 2010.

52. Hervieu V, Lepinasse F, Gouysse G, et al: Expression of $\beta$-catenin in gastroenteropancreatic endocrine tumours: a study of 229 cases. J Clin Pathol 59: 1300-1304, 2006

53. Lin SY, Xia W, Wang JC, et al: $\beta$-catenin, a novel prognostic marker for breast cancer: its roles in cyclin D1 expression and cancer progression. Proc Nat Acad Sci USA 97: 4262-4266, 2000.

54. Wong SC, Lo ES, Lee KC, Chan JK and Hsiao WL: Prognostic and diagnostic significance of $\beta$-catenin nuclear immunostaining in colorectal cancer. Clin Cancer Res 10: 1401-1408, 2004. 